\title{
Uspješno liječenje pityriasis lichenoides et varioliformis acuta u pacijenta s kroničnom hiperuricemijom
}

\section{Successful treatment of pityriasis lichenoides et varioliformis acuta in a patient with chronic hyperuricemia}

\author{
Dora Gašparini ${ }^{1 *}$, Marija Kaštelan²
}

\author{
${ }^{1}$ Medicinski fakultet, Sveučilište u Rijeci, \\ Rijeka \\ ${ }^{2}$ Katedra za dermatovenerologiju, \\ Medicinski fakultet, Sveučilište u Rijeci, \\ KBC Rijeka, Rijeka
}

Sažetak. Cilj: Prikazati slučaj pacijenta s pityriasis lichenoides et varioliformis acuta, s predstavljanjem dijagnostičkih i terapijskih izazova ovog kliničkog entiteta. Prikaz slučaja: Tridesetogodišnji pacijent upućen je na Kliniku za dermatovenerologiju zbog kožnih promjena popraćenih svrbežom u trajanju od mjesec i pol dana. Crvene papule i papulokruste bile su prisutne na trupu, gornjim i donjim ekstremitetima, no na gornjim i donjim ekstremitetima bile su brojnije $i$ jače izražene nego na trupu. Pacijent je naveo da je povremeno uzimao febuksostate za liječenje kronične hiperuricemije tijekom posljednje četiri godine. Započeta je lokalna terapija kombinacijom betametazona i gentamicina te peroralnim desloratadinom. U krvnoj slici uočene su neutropenija, povišene vrijednosti kolesterola lipoproteina niske gustoće i povišene vrijednosti urata. Učinjena je biopsija kožne promjene, a pacijentu je preporučen doksiciklin uz nastavak liječenja betametazonom i gentamicinom. Patohistološki nalaz opisivao je ulcerirani epidermis $s$ edemom, granulacijskim tkivom i ekstravazacijom eritrocita u dnu ulceracije. Prema bazi ulceracije i subepidermalno nalazili su se infiltrati limfocita i histiocita, a epidermis je na rubovima ulceracije bio nepravilno hiperplastičan $s$ izraženom spongiozom. Time je potvrđena dijagnoza pityriasis lichenoides et varioliformis acuta. Po završetku liječenja doksiciklinom došlo je do potpune regresije kožnih promjena i sniženja vrijednosti urata. Zaključci: U pacijenata s dijagnozom pityriasis lichenoides et varioliformis acuta potreban je povećan oprez u dijagnosticiranju i liječenju te redovito praćenje stanja zbog širokog spektra diferencijalnih dijagnoza i mogućnosti postavljanja krive dijagnoze. Nužna su daljnja istraživanja o etiopatogenetskoj osnovi ove bolesti s ciljem upotrebe tih znanja u uspješnijem liječenju.

Ključne riječi: doksiciklin; kožne bolesti; parapsorijaza; pityriasis lichenoides

Abstract. Aim: To report a case of a patient with pityriasis lichenoides et varioliformis acuta, emphasising the challenges in the diagnosis and treatment of this clinical entity. Case report: A 30-year-old patient was referred to the Department of Dermatology and Venereology due to skin changes accompanied by itching persisting for one and a half month. Red papules and papulocrusts were found on the trunk, upper and lower limbs, but in a larger number and more severely affecting the trunk than the limbs. The patient stated the occasional use of febuxostat for the treatment of chronic hyperuricemia that has been diagnosed four years prior. Treatment with desloratadine and a combination of bethametasone and gentamicin was started. The laboratory results showed neutropenia, high levels of low density lipoprotein cholesterol and high levels of urate. The biopsy of the skin lesion has been done. Doxycycline treatment and continuing treatment with bethametasone and gentamicin were recommended to the patient. Pathohistological finding described ulcerated epidermis with oedema, granulation tissue and erythrocyte extravasation in the floor of the ulceration. Lymphocytic and histiocytic infiltrates were found in the base of the ulceration and subepidermally. The epidermis on the edge of the ulceration was irregularly hyperplastic and showed spongiosis. The diagnosis of pityriasis lichenoides et varioliformis acuta has been

http://hrcak.srce.hr/medicina 
confirmed. Upon completion of doxycycline treatment skin changes were in regression and urate levels decreased. Conclusions: Not only caution in diagnosis and treatment, but also regular follow-up is necessary in patients diagnosed with pityriasis lichenoides et varioliformis acuta because of a wide range of differential diagnoses and a possibility of misdiagnosis. Further research on the etiopathogenesis of this disorder is needed in order to improve treatment outcomes.

Key words: doxycycline; parapsoriasis; pityriasis lichenoides; skin diseases

\section{UVOD}

Pityriasis lichenoides (lat. PL) ili parapsoriasis guttata kožna je bolest nepoznate etiologije koja se pojavljuje u djece i mladih odraslih ljudi ${ }^{1}$. Razlikuju se dva klinička oblika: pityriasis lichenoides chronica (lat. PLC) i pityriasis lichenoides et varioliformis acuta (lat. PLEVA). Poznato je da PL tri puta češće zahvaća muškarce nego žene i da se PLEVA pojavljuje šest puta rjeđe od PLC-a, no uzrok ovih razlika u pojavnosti i točna prevalencija PLEVA-e u općoj populaciji nisu poznati ${ }^{1,2}$. PLEVA ili Mucha-Habermannova bolest rijetka je idiopatska stečena dermatoza obilježena eritematoskvamoznim papulama, često popraćenim hemoragičnim, papulovezikularnim i papulonekrotičnim lezijama s varioliformnim ožiljkavanjem. Opće stanje pacijenata obično nije narušeno. U ovom članku prikazan je slučaj pacijenta s PLEVA-om s predstavljanjem dijagnostičkih i terapijskih izazova ovog kliničkog entiteta.

\section{PRIKAZ SLUČAJA}

Tridesetogodišnji pacijent upućen je na Kliniku za dermatovenerologiju Kliničkog bolničkog centra Rijeka zbog kožnih promjena popraćenih svrbežom u trajanju od mjesec i pol dana. Crvene papule i papulokruste bile su prisutne na trupu (slika 1A), gornjim (slika 1B, slika 1C) i donjim ekstremitetima (slika 1D, slika $1 E$ ), no na gornjim i donjim ekstremitetima bile su brojnije i jače izražene nego na trupu. Pacijent je naveo da je povremeno uzimao febuksostate za liječenje kronične hiperuricemije tijekom posljednje četiri godine, no mjesec dana prije pojave kožnih promjena pacijent nije uzimao navedeni lijek. Obiteljska anamneza bila je opterećena kroničnom hiperuricemijom oca. Započeta je terapija kombinacijom betametazona i gentamicina u obliku masti te desloratadinom u obliku tableta. Dva tjedna nakon prvog pregleda pacijent je došao na kontrolni pregled te su tada u krvnoj slici uočene neutropenija (36,6\% ukupnog broja leukocita, referentni interval: $44-72 \%$ ), blaga limfocitoza (48,6 \% ukupnog broja leukocita, referentni interval: $20-46 \%)$, blaga hiperkolesterolemija $(5,6$ mmol L $\mathrm{L}^{-1}$, preporučene vrijednosti: $<5 \mathrm{mmol} \mathrm{L}^{-1}$ ),

Buduća istraživanja trebala bi ustanoviti postoji li povezanost između individualnih karakteristika i komorbiditeta pacijenata i učinkovitosti liječenja pojedinim terapijskim opcijama. Usto, osnovni korak u uspješnijem liječenju ovog kožnog poremećaja je uspostavljanje poveznice s etiopatogenezom bolesti i razvijanje selektivnih lijekova usmjerenih na pojedine sastavnice imunosnog odgovora u podlozi.

povišene vrijednosti kolesterola lipoproteina niske gustoće (engl. low density lipoprotein, LDL; $3,8 \mathrm{mmol} \mathrm{L}^{-1}$, preporučene vrijednosti: < $3 \mathrm{mmol}$ $\left.\mathrm{L}^{-1}\right)$ i povišene vrijednosti urata $\left(525 \mu \mathrm{mol} \mathrm{L} \mathrm{L}^{-1}\right.$, referentni interval za muškarce: 182 - $403 \mu \mathrm{mol}$ $\left.\mathrm{L}^{-1}\right)$. Bris ždrijela i hemokulture uzeti prvi prvom pregledu bili su negativni. Učinjena je biopsija kožne promjene na lijevoj nadlaktici, a pacijentu su preporučene doksiciklin tablete $2 \times 100 \mathrm{mg}$ tijekom 10 dana i nakon 10 dana 1 x 100 mg uz nastavak liječenja betametazonom i gentamicinom u obliku masti. Patohistološki nalaz opisivao je ulcerirani epidermis s edemom, granulacijskim tkivom i ekstravazacijom eritrocita u dnu ulceracije. Prema bazi ulceracije i subepidermalno nalazili su se infiltrati limfocita i histiocita, a epidermis je na rubovima ulceracije bio nepravilno hiperplastičan s izraženom spongiozom. Time je potvrđena dijagnoza pityriasis lichenoides et varioliformis acuta. Kontrolni laboratorijski nalazi bili su uredni osim povišenih vrijednosti urata (492 $\left.\mathrm{mmol} \mathrm{L}^{-1}\right)$, ukupnog kolesterola $\left(6,4 \mathrm{mmol} \mathrm{L}^{-1}\right)$ i LDL-kolesterola $\left(4,3 \mathrm{mmol} \mathrm{L}^{-1}\right)$. Pacijent je redovito dolazio na kontrolne preglede. Došlo je do potpune regresije kožnih promjena i sniženja vrijednosti urata po završetku liječenja doksiciklinom. Sniženje vrijed- 
nosti urata bilo je primjetno, iako je njihova razina još uvijek bila iznad referentnih vrijednosti. Nakon izlječenja PLEVA-e pacijent više nije dolazio na kontrolne preglede, stoga uvid u daljnju dinamiku kretanja vrijednosti urata nije bio moguć.

\section{RASPRAVA}

Dosad nije opisan nijedan slučaj hiperuricemije u krvnoj slici pacijenta prilikom nastupa PLEVA-e. Snižavanje vrijednosti urata u krvi pojavilo se usporedno $s$ regresijom kožnih promjena u našeg pacijenta, što upućuje na moguću poveznicu ovih dvaju kliničkih entiteta, no dvojbeno je ima li povišena razina urata u krvi izravnog utjecaja na pojavu PLEVA-e. S obzirom na to da je etiopatogeneza PLEVA-e još uvijek nedovoljno razjašnjena, nužna su daljnja istraživanja kojima bi se ona detaljnije opisala i razjasnila. U literaturi su navedene sljedeće teorije o njezinom nastanku: (1) reakcija preosjetljivosti na uzročnike infekcija poput virusa humane imunodeficijencije, citomegalovirusa, Epstein-Barrova virusa, varicella zoster virusa, humanog herpesvirusa 7, coxsackie A virusa, adenovirusa i parvovirusa B19, parazita Toxoplasma gondii te bakterija iz roda Mycoplasma spp., Streptococcus spp. i Staphylococcus spp.; (2) reakcija preosjetljivosti na lijekove poput estrogena, progesterona i različitih kemoterapeutika te na cjepiva protiv gripe i protiv morbila, parotitisa i rubeole; (3) limfoproliferativno podrijetlo zbog klonalne proliferacije T limfocita u $50 \%$ pacijenata s PLEVA-om; (4) vaskulitis posredovan imunokompleksima koji je najviše izražen u teškom i smrtonosnom febrilno-ulceroznom obliku bole$\mathrm{sti}^{3-19}$. Najdetaljnije su proučavana imunosna zbivanja $u$ pacijenata $u$ kojih je dijagnosticirana PLEVA. Uočeni infiltrat citotoksičnih limfocita u dermisu i epidermisu posljedica je imunosnog odgovora na promijenjene antigene epidermisa, potencijalno zbog indukcije nepoznatim infektivnim čimbenikom ${ }^{13,20}$. Pojedini znanstvenici svrstavaju PLEVA-u u spektar klonalnih limfocitima $T$ posredovanih kožnih poremećaja, dok drugi opisuju preinake u genima koji kodiraju monoklonalni T-stanični receptor (engl. $T$ cell receptor, $\mathrm{TCR})^{21,22}$. Smatra se da PLEVA pripada benignim klonalnim T-staničnim poremećajima ${ }^{23,24}$. Nejasno je jesu li promjene u TCR-u posljedica predomi- nacije klona preneoplastičnih T-limfocita ili one predstavljaju imunosni odgovor na pretpostavljeni unutarstanični patogen posredovan klonom citotoksičnih T-limfocita ${ }^{25}$. Sličnost i moguća povezanost $\mathrm{s}$ malignim oboljenjima limfocita $\mathrm{T}$ zahtijeva dugotrajno praćenje pacijenata s ovim kožnim promjenama.

Postavljanje dijagnoze PLEVA-e temelji se na razlučivanju PLEVA-e od sljedećih stanja i poremećaja: limfomatoidna papuloza, varicella, Gianotti-Crostijev sindrom, erythema multiforme, pityriasis rosea, psoriasis guttata, leukocitoklastični vaskulitis, ubod kukca i sekundarni sifilis ${ }^{16,19,26,27}$. Dijagnozu PLEVA-e postavljenu samo na temelju kliničkog pregleda trebalo bi u slučaju perzistiranja kožnih promjena potvrditi patohistološkim nalazom. Dijagnostički izazov se osim u velikom spektru diferencijalnih dijagnoza sastoji i u pravovremenom prepoznavanju ovog stanja zbog moguće progresije bolesti u febrilnu ulceronekrotičnu Mucha-Habermannovu bolest (engl. febrile ulceronecrotic Mucha-Habermann disease, FUMHD), najtežu kliničku inačicu PLEVA-e koja je karakterizirana naglim nastupom ulceronekrotičnih kožnih lezija popraćenih visokom temperaturom (do $40{ }^{\circ} \mathrm{C}$ ), zimicom, tresavicom, artralgijama, mialgijama, kardiomiopatijom ili limfocitnim miokarditisom, reumatološkim simptomima, megaloblastičnom anemijom, pancitopenijom i diseminiranom intravaskularnom koagulacijom te slabošću i umorom s gastrointestinalnim, neurološkim i plućnim simptomima ili bez njh 7,12,28-31. FUMHD se češće pojavljuje u dječjoj i mlađoj odrasloj dobi te u osoba muškog spola. Srednja dob dosad opisanih slučajeva iznosi 27,4 godine (raspon $4-82$ ), a $75 \%$ pacijenata bilo je mlađe od 35 godina u trenutku pojave bolesti ${ }^{32}$. Naš se pacijent uklapa u navedeni epidemiološki profil. S napredovanjem bolesti koža zbog nastalog oštećenja postaje podložnija bakterijskim infekcijama. FUMHD može započeti kao blagi oblik kožnih promjena koje odgovaraju dijagnozi PLEVA-e iz kojih se zatim razviju velike ulceronekrotične lezije ili odmah kao akutno nastale opsežne papulonekrotične i hemoragične kožne promjene difuzno raširene po cijelome tijelu ${ }^{32}$. Ulkusi često postanu sekundarno inficirani i imaju tendenciju cijeljenja per secundam i cijeljenja hi- 
pertrofičnim ožiljcima ${ }^{31}$. U pacijenata s FUMHDom mogu biti zahvaćene sluznice usne šupljine, genitalija i spojnice oka ${ }^{18}$. Kortikosteroidi nisu dovoljno učinkoviti u liječenju ove inačice PLEVA-e. Remisija se ponekad postiže uvođenjem metotreksata, no ovo se stanje često ne prepozna te se liječi aciklovirom, antibioticima i topičkim kortikosteroidima. Stopa mortaliteta u pacijenata s FUMHD-om iznosi oko $20 \%$ u dosad opisanim slučajevima, ali s obzirom na to da u djece do 14 godina nije opisan nijedan smrtni slučaj, ova stopa se u pacijenata starijih od 14 godina penje na $33,3 \%{ }^{29}$. Uzroci mortaliteta uključuju: plućnu tromboemboliju, pneumoniju, infarkt miokarda, sepsu, hipovolemijski šok i masivnu trombozu gornje mezenterične arterije $\mathrm{e}^{29-31}$.

Nekoliko mogućih načina liječenja PLEVA-e opisano je, ali do danas nema jasno određene terapijske metode koja se preporučuje svim pacijentima. Svi pacijenti prikazani u literaturi bili su liječeni s nekoliko terapijskih opcija istovremeno, a one su uključivale: sustavne kortikosteroide, metotreksat, ciklosporin, infliksimab, eritromicin, tetraciklin, minociklin, psoralen uz ultraljubičasto A-zračenje (engl. psoralen and ultraviolet $A$; PUVA), ultraljubičasto B-zračenje (engl. ultravio-
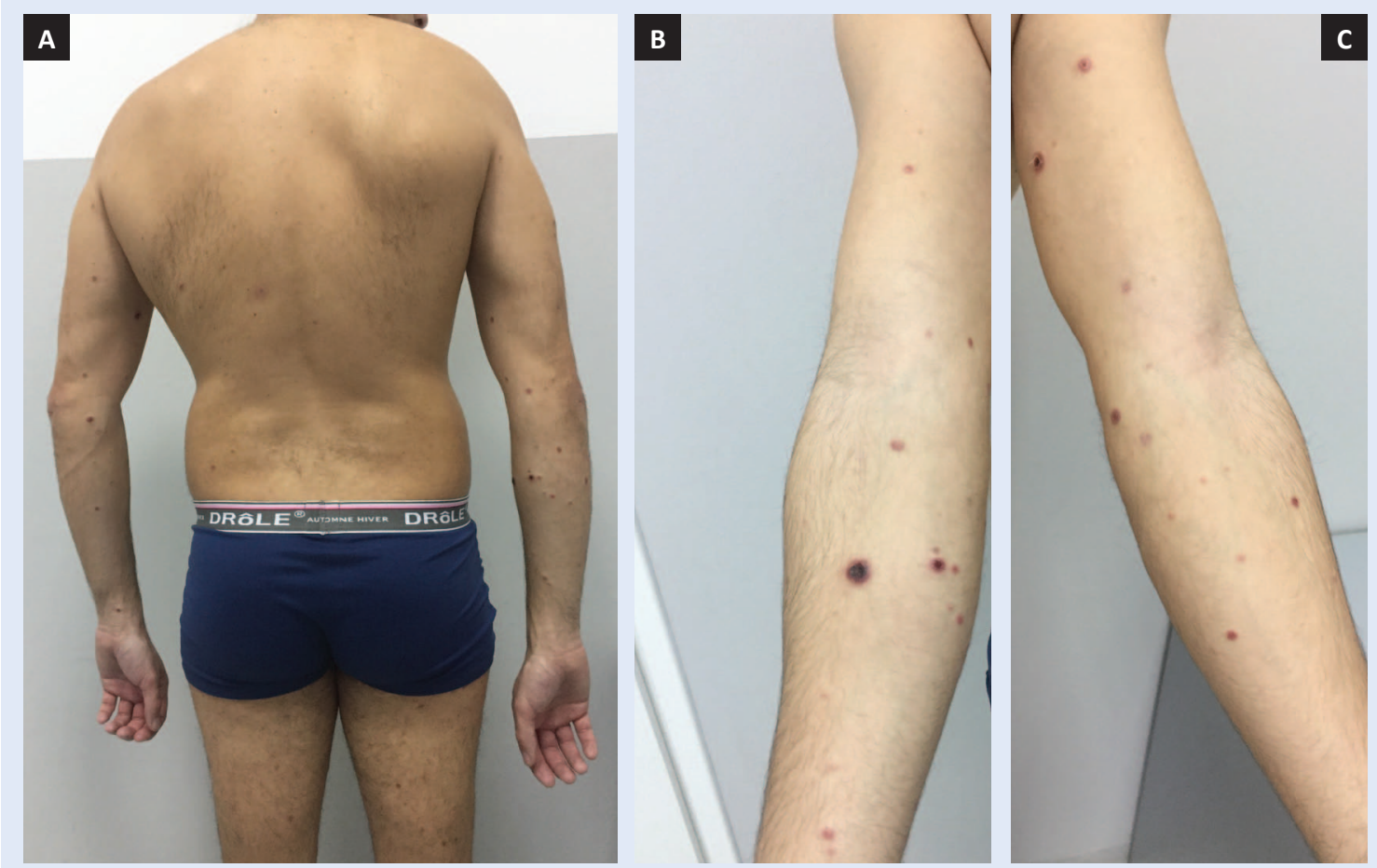

Slika 1. Crvene papule i papulokruste na stražnjem dijelu trupa i stražnjim površinama gornjih ekstremiteta i natkoljenica (A), na desnoj nadlaktici i podlaktici (B), na lijevoj nadlaktici i podlaktici $(C)$, na prednjoj površini lijeve i desne natkoljenice (D), na stražnjim površinama natkoljenice i proksimalnog dijela potkoljenice lijeve noge te natkoljenice desne noge (E).

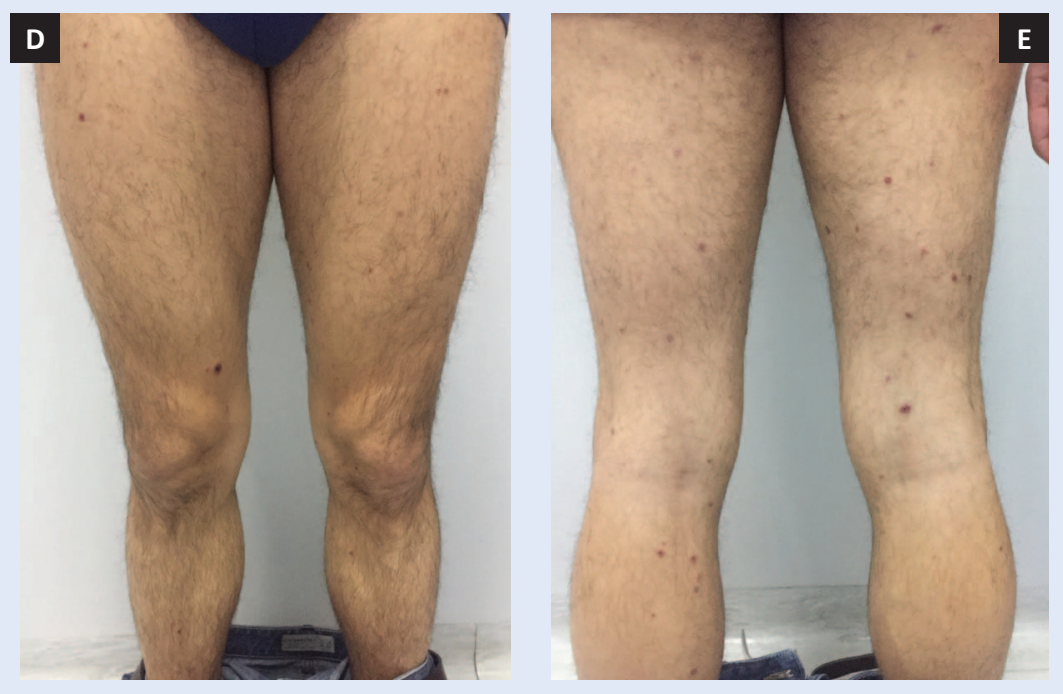


let; UVB), aciklovir, intravenski imunoglobulin i 4,4-diamino-difenil sulfon 1,19,25,32-39. Teško je procijeniti učinkovitost navedenih terapijskih modaliteta s obzirom na to da nijedan lijek nije uspio postići remisiju bolesti u svim slučajevima. Najbolji terapijski odgovor zabilježen je kod primjene metotreksata koju obilježava brza remisija, čak i u slučajeva refraktornih na ostale načine liječenja ${ }^{32}$. U našem je slučaju liječenje doksiciklinom rezultiralo potpunim povlačenjem kožnih promjena. Buduća istraživanja trebala bi utvrditi postoji li

$\mathrm{U}$ pacijenata s dijagnozom pityriasis lichenoides et varioliformis acuta potreban je povećan oprez u dijagnosticiranju i liječenju te redovito praćenje stanja $u$ pacijenata s ovim ili sličnim kožnim promjenama zbog širokog spektra diferencijalnih dijagnoza i mogućnosti postavljanja krive dijagnoze.

povezanost između individualnih obilježja i komorbiditeta pacijenata, poput kronične hiperuricemije u ovom slučaju, i učinkovitosti liječenja pojedinim terapijskim opcijama. Osnovni korak k uspješnijem liječenju ovog kožnog poremećaja je razumijevanje etiopatogenetske osnove bolesti, čime bi se omogućio razvoj lijekova usmjerenih na pojedine sastavnice imunosnog odgovora $u$ podlozi.

\section{ZAKLJUČCI}

$\mathrm{U}$ pacijenata $\mathrm{s}$ dijagnozom pityriasis lichenoides et varioliformis acuta potreban je povećan oprez u dijagnosticiranju i liječenju te redovito praćenje stanja zbog širokog spektra diferencijalnih dijagnoza i mogućnosti postavljanja krive dijagnoze. Nužna su daljnja istraživanja o etiopatogenetskoj osnovi ove bolesti s ciljem upotrebe tih znanja u uspješnijem liječenju.

Izjava o sukobu interesa: Autori izjavljuju da ne postoji sukob interesa.

\section{LITERATURA}

1. Zang JB, Coates SJ, Huang J, Vonderheid EC, Cohen BA. Pityriasis lichenoides: Long-term follow-up study. Pediatr Dermatol 2018;35:213-9.

2. Romaní J, Puig L, Fernández-Figueras MT, de Moragas JM. Pityriasis lichenoides in children: Clinicopathologic review of 22 patients. Pediatr Dermatol 1998;15:1-6.
3. Fölster-Holst R, Zawar VP, Chuh A. Paraviral exanthems. Expert Rev Anti Infect Ther 2016;14:601-11.

4. Ostlere LS, Langtry JAA, Branfoot AC, Staughton RCD. HIV seropositivity in association with pityriasis lichenoides et varioliformis acuta. Clin Exp Dermatol 1992;17:36-7.

5. Relvas M, Santiago L, Cardoso JC, Oliveira H. Pityriasis lichenoides et varioliformis acuta as presenting feature of acute human immunodeficiency virus infection. BMJ Case Rep 2019;12:e231864.

6. Smith KJ, Nelson A, Skelton H, Yeager J, Wagner KF. Pityriasis lichenoides et varioliformis acuta in HIV1 patients: a marker of early stage disease. Int J Dermatol 1997;36:104-9.

7. Tsai KS, Hsieh HJ, Chow KC, Lin TY, Chiang SF, Huang HH. Detection of cytomegalovirus infection in a patient with febrile ulceronecrotic Mucha-Habermann's disease. Int J Dermatol 2001;40:694-8.

8. Edwards BL, Bonagura VR. Mucha-Habermann's disease and arthritis: possible association with reactivated Epstein-Barr virus infection. J Rheumatol 1989;16:387-9.

9. Cho E, Jun HJ, Cho SH, Lee JD. Varicella-Zoster Virus As a Possible Cause of Pityriasis Lichenoides et Varioliformis Acuta. Pediatr Dermatol 2014;31:259-60.

10. Horie C, Mizukawa Y, Yamazaki Y, Shiohara T. Varicella zoster virus as a possible trigger for the development of pityriasis lichenoides et varioliformis acuta: retrospective analysis of our institutional cases. Clin Exp Dermatol 2018;43:703-7.

11. Costa-Silva M, Calistru A, Sobrinho-Simões J, Lisboa C, Azevedo F. Pityriasis Lichenoides et Varioliformis Acuta Associated With Human Herpesvirus 7. Actas Dermosilfilogr 2018;109:6-10.

12. Auster BI, Santa Cruz DJ, Eisen AZ. Febrile ulceronecrotic Mucha-Habermann's disease with interstitial pneumonitis. J Cutan Pathol 1979;6:66-76.

13. Tomasini D, Tomasini CF, Cerri A, Sangalli G, Palmedo G, Hantschke $M$ et al. Pityriasis lichenoides: a cytotoxic Tcell-mediated skin disorder. Evidence of human parvovirus B19 DNA in nine cases. J Cutan Pathol 2004;31:531-8.

14. Rongioletti F, Delmonte S, Rebora A. Pityriasis lichenoides and acquired toxoplasmosis. Int J Dermatol 1999;38: 372-4.

15. English JC III, Collins M, Bryant-Bruce C. Pityriasis lichenoides et varioliformis acuta and group $A$ beta hemolytic streptococcal infection. Int J Dermatol 1995;34:642-6.

16. de Castro BA, Pereira JM, Meyer RL, Trindade FM, Pedrosa MS, Piancastelli AC. Pityriasis lichenoides et varioliformis acuta after influenza vaccine. An Bras Dermatol 2015;90:181-4.

17. Gil-Bistes D, Kluger N, Bessis D, Guillot B, Raison-Peyron N. Pityriasis lichenoides chronic after measles-mumpsrubella vaccination. J Dermatol 2012;39:492-3.

18. Gunatheesan S, Ferguson J, Moosa Y. Pityriasis lichenoides et varioliformis acuta: a rare association with the measles, mumps and rubella vaccine. Australas J Dermatol 2012;53:76-8.

19. Bowers S, Warshaw EM. Pityriasis lichenoides and its subtypes. J Am Acad Dermatol 2006;55:557-72.

20. Kempf W, Kazakov DV, Palmedo G, Fraitag S, Schaerer L, Kutzner, H. Pityriasis lichenoides et varioliformis acuta with numerous $\mathrm{CD} 30(+)$ cells: a variant mimicking lymphomatoid papulosis and other cutaneous lymphomas. A clinicopathologic, immunohistochemical, and molecular 
biological study of 13 cases. Am J Surg Pathol 2012;36: 1021-9.

21. Dereure O, Levi E, Kadin ME. T-cell clonality in pityriasis lichenoides et varioliformis acuta: a heteroduplex analysis of 20 cases. Arch Dermatol 2000;136:1483-6.

22. Weinberg JM, Kristal L, Chooback L, Honig PJ, Kramer EM, Lessin SR. The clonal nature of pityriasis lichenoides. Arch Dermatol 2002;138:1063-7.

23. Magro C, Crowson AN, Kovatich A, Burns F. Pityriasis lichenoides: a clonal T-cell lymphoproliferative disorder. Hum Pathol 2002;33:788-95.

24. Moy A, Sun J, Ma S, Seminario-Vidal L. Lymphomatoid Papulosis and Other Lymphoma-Like Diseases. Dermatol Clin 2019;37:471-82.

25. Helmbold P, Gaisbauer G, Fiedler E, Stücker M, Wolter M, Marsch W. Self-limited variant of febrile ulceronecrotic Mucha-Habermann disease with polyclonal T-cell receptor rearrangement. J Am Acad Dermatol 2006;54: 1113-5.

26. Lejuste FX, Michaux C, Lehners C, Calteux N. Febrile ulceronecrotic Mucha-Habermann disease. BMJ Case Rep 2013;2013:bcr2013009739.

27. Zheng $Y$, Jia J, Tian $Q$, Dong $X$, Wang $X$, Zhaoxia $Y$ et al. Lymphomatoid papulosis misdiagnosed as pityriasis lichenoides et varioliformis acuta: Two case reports and a literature review. Exp Ther Med 2014;8:1927-33.

28. Ito N, Ohshima A, Hashizume H, Takigawa M, Tokura Y. Febrile ulceronecrotic Mucha-Habermann's disease managed with methylprednisolone semipulse and subsequent methotrexate therapies. J Am Acad Dermatol 2003; 49:1142-8.

29. Miyamoto T, Takayama N, Kitada S, Hagari Y, Mihara M. Febrile ulceronecrotic Mucha-Habermann disease: a case report and a review of the literature. J Clin Pathol 2003;56:795-7.

30. Malnar T, Milavec-Puretic V, Rados J, Zarkovic K, Dobric I. Febrile ulceronecrotic pityriasis lichenoides et varioliformis acuta with fatal outcome. J Eur Acad Dermatol Venereol 2006;20:303-7.
31. Sotiriou E, Patsatsi A, Tsorovava C, Lazaridou E, Sotiriadis D. Febrile Ulceronecrotic Mucha-Habermann Disease: A Case Report and Review of the Literature. Acta Derm Venereol 2008;88:350-5.

32. Tsianakas A, Hoeger PH. Transition of pityriasis lichenoides et varioliformis acuta to febrile ulceronecrotic Mucha-Habermann disease is associated with elevated serum tumour necrosis factor-alpha. $\mathrm{Br} J$ Dermatol 2005;152:794-9.

33. Kim HS, Yu DS, Kim JW. A case of febrile ulceronecrotic Mucha-Habermann disease tretad with oral cyclosporine. J Eur Acad Derm Venereol 2007;21:247-89.

34. Khachemoune A, Blyumin ML. Pityriasis lichenoides. Pathophysiology, classification, and treatment. Am J Clin Dermatol 2007;8:29-36.

35. Pyrpasopoulou A, Athyros VG, Karagiannis A, Chrysomallis $F$, Zamboulis $C$. Intravenous immunoglobulins: a valuable asset in the treatment of a case of septic febrile ulceronecrotic Mucha-Habermann disease. Dermatology 2007;215:164-5.

36. Marenco F, Fava P, Fierro MT, Quaglino P, Bernengo MG. High-dose immunoglobulins and extracorporeal photochemotherapy in the treatment of febrile ulceronecrotic Mucha-Habermann disease. Dermatol Ther 2010;23: 419-22.

37. Lis-Święty A, Michalska-Bańkowska A, Zielonka-Kucharzewska A, Pypłacz-Gumprecht A. Successful therapy of cyclosporin $A$ in pityriasis lichenoides et varioliformis acuta preceded by hand, foot and mouth disease. Antivir Ther 2016;21:273-5.

38. Van TN, Thi TN, Huu DL, Huu ND, Thi ML, Minh TN et al. Clinical Aspects and Treatment of Pityriasis Lichenoides Et Varioliformis Acuta: A Retrospective Vietnamese Study. Open Access Maced J Med Sci 2019;7:198-9.

39. Maranda EL, Smith M, Nguyen AH, Patel VN, Schachner LA, Joaquin JJ. Phototherapy for pityriasis lichenoides in the pediatric population: a review of the published literature. Am J Clin Dermatol 2016;17:583-91. 